\title{
Effect of Pinching on Growth and Flower Production of Marigold
}

\author{
Asif Khan, Muhammad Waseem Abbas*, Safi Ullah, Atta Ullah, Siyad Ali, Atta Ullah Khan, Uzair Khan and Maaz \\ Khan
}

The University of Agriculture, Pakistan

Submission: October 14, 2018; Published: October 24, 2018

*Corresponding author: Asif Khan, The University of Agriculture, Peshawar, Pakistan

Abstract

An experiment was conducted on the effect of pinching on growth and flower production of marigold at Ground and cover nursery, in the Department of Horticulture, the University of Agriculture Peshawar during autumn 2017. The experiment was conducted in complete randomized design with four repetitions. Marigold was pinched at a different height $(0,1$ foot $)$. Analysis of data revealed that pinching had a significant effect on most of the attributes of marigold. Regarding pinching a maximum number of branches (12.41), days to 50\% flowering (54.9), plant height $(34.43 \mathrm{~cm})$, flower diameter (4.58), stem diameter $(0.76 \mathrm{~cm})$ and a number of flowers (9.93) was observed in pinched plants. It was concluded from the above results that marigold could be pinched at I feet height for significant growth and flower production.

\section{Introduction}

Marigold is botanically identified Tagetes (Compositae or Asteraceae). During growth stage of Marigold, a stage come at which the plant become bushy the reason is the overgrowth of the lateral branches which lead stop aeration in the plant inside which ultimately increase the humidity level and make the favorable environment for pathogens and the pest to attack the plant. Its species vary in size from 0.1 to $2.2 \mathrm{~m}$ tall. Blooms naturally occur in golden, orange, yellow, and white colors, often with maroon highlights. They have fibrous roots [1]. Depending on the species, Tagetes species grow well in almost any sort of soil. Most horticultural selections grow best in soil with good drainage, even though some cultivars are known to have good tolerance to drought [2]. Due to the greater number of branches, the number of flowers comes in large quantity but small in size (diameter is small) the reason was that the nutrients and other minerals contents are utilized in promoting the vegetative growth [3]. Pinching help out the plant to prevent the bushy growth, use your thumb and forefinger to pinch out the top growth of the plants. For cutting use sharp knife. Removal of the apical portion of the shoot is known as pinching. It was observed that pinching at 40 days after transplanting increase flower yield. Marigold native to the new world and sacred flower of the Aztec, journey across the Atlantic Ocean twice to travel 3,000 miles north of their center of origin. Marigold flowers are plucked when they have attained full size. Plucking of flowers should be done in the cool hours of the day. The field should be irrigated before plucking so that flowers keep well for a longer period after harvest. Plucked flowers are packed in polythene bags or bamboo baskets for carrying to markets. Due to excessive vegetative growth, the plant continuous the upright growth and at the end becomes very tall which results in the bending of the plant and then need stacking to support the plant. To find out optimum pinching length on flower production of marigold.

\section{Methods and Material}

A field trial was conducted on the effect of pinching on growth and flower production of marigold at ground and cover nursery, in the Department of Horticulture, The University of Agriculture Peshawar, during autumn 2017. The experimental site is located $331 \mathrm{~m}$ height from the sea level $\left(34.015^{\circ} \mathrm{N}, 71.5249^{\circ} \mathrm{E}\right)$. The soil has $7.9 \mathrm{pH}$, Warm to hot is the climatic condition (semi-arid subtropical) receiving $<500 \mathrm{~mm}$ annual precipitation (ppt) with daily average temperature varying from 400-500C in summer however in winter it is from 70-130C. The experiment was conducted in the randomized complete block design, with four repetitions. Marigold was pinched at the different height $(0$ and 1 foot height) with 4 replications, studied its different growth attributes. The experiment was conducted in pots, each pot has 3 marigold plants and the total number of pots selected was 12 . So about 30 plants were planted in pots each pot contain 3 plants of marigold. The parts are placed in 4 replications. To know the effect of pinching the control plants were also selected so that the parameters of the pinched and non-Pinched plant were compared. Data were collected on the following parameters Plant height.
a) Number of branches.
b) Number of flowers. 
c) Stem diameter.

d) Flower diameter.

e) Day to sprouting.

\section{Results and Discussion}

\section{Number of Branches Plant ${ }^{-1}$}

The analysis of variance indicated that pinching had a significant effect on the number of branches plant-1 of marigold. The mean data indicated that the maximum number of branches plant-1 (12.41) was recorded in the plant that was pinched at 1 foot, whereas the minimum number of branches plant-1 (10.55) was observed in the non-pinched plant (control treatment) (Table 1). Increased number of branches due to pinching might be attributed to the breaking of apical dominance and sprouting of auxiliary buds as observed in the present study. Similar results were also reported by [4].

\section{Days to $\mathbf{5 0 \%}$ Flowering}

Table 1: Mean Table. Number of branches plant ${ }^{-1}$, plant height and days to $50 \%$ flowering as affected by pinching.

\begin{tabular}{|c|c|c|c|}
\hline Treatments & $\begin{array}{c}\text { No. of branches } \\
\text { plant }^{-1}\end{array}$ & $\begin{array}{c}\text { Plant height } \\
\text { (cm) }\end{array}$ & $\begin{array}{c}\text { Days to 50\% } \\
\text { flowering }\end{array}$ \\
\hline Control & $10.55 \mathrm{~b}$ & $34.43 \mathrm{a}$ & 50.56 \\
\hline Pinched & $12.41 \mathrm{a}$ & $22.85 \mathrm{~b}$ & 54.99 \\
\hline LSD $\leq 0.05$ & 0.62 & 5.03 & NS \\
\hline
\end{tabular}

The analysis of variance showed that pinching had no significant effect on number days to $50 \%$ flowering of marigold. However, the mean data revealed that maximum days (54.99) to $50 \%$ flowering was taken by the pinched plant, whereas minimum days to $50 \%$ flowering (50.56) was observed in nonpinched plants (control treatment) (Table 1). It might be due to the fact that new shoots which emerged after pinching entered into vegetative phase and took time to become physiologically mature to bear flowers [5].

\section{Height of Plant ${ }^{-1}$}

The analysis of variance indicated that pinching had a significant effect on plant height of marigold. The mean data showed that maximum plant height- $1(34.43 \mathrm{~cm})$ was recorded in pinched plant and the minimum plant height ${ }^{-1}(22.85 \mathrm{~cm})$ was recorded in non-pinched plant (Table 1). Pinched plants are less in height because the apical portion was cut during pinching and control plants are more in height because there was no pinching involved.

\section{Flower Diameter}

The analysis of variance showed that pinching had a significant effect on flower diameter of marigold. The mean data revealed that maximum flower diameter $(4.58 \mathrm{~cm})$ was recorded in pinched plant and the minimum flower diameter $(3.45 \mathrm{~cm})$ was recorded in a non-pinched plant of marigold (Table 2). Mean data showed that maximum flower diameter $(4.58 \mathrm{~cm})$ was recorded in pinched plant and the minimum flower diameter
$(3.45 \mathrm{~cm})$ was recorded in a non-pinched plant of marigold. The data revealed that pinching had a significant effect on increasing size of flowers which ultimately increased the flower diameter.

Table 2: Number of flower plant $^{-1}$, flower diameter and stem diameter of marigold as affected by pinching.

\begin{tabular}{|c|c|c|c|}
\hline Treatment & $\begin{array}{c}\text { No. of flower } \\
\text { plant }^{-1}\end{array}$ & $\begin{array}{c}\text { Flower } \\
\text { diameter }(\mathbf{c m})\end{array}$ & $\begin{array}{c}\text { Stem diameter } \\
\text { (cm) }\end{array}$ \\
\hline Control & $6.44 \mathrm{~b}$ & $3.45 \mathrm{~b}$ & $0.60 \mathrm{a}$ \\
\hline Pinched & $9.93 \mathrm{a}$ & $4.58 \mathrm{a}$ & $0.76 \mathrm{~b}$ \\
\hline LSD $\leq 0.05$ & 0.95 & 0.57 & 0.05 \\
\hline
\end{tabular}

\section{Stem Diameter}

The analysis of variance indicates that pinching had a significant effect on stem diameter of marigold. The mean data showed that maximum stem diameter $(0.76 \mathrm{~cm})$ was recorded in pinched plant and the minimum stem diameter $(0.60 \mathrm{~cm})$ was recorded in a non-pinched plant of marigold (Table 2). The mean data showed that maximum stem diameter $(0.76 \mathrm{~cm})$ was recorded in pinched plant and the minimum stem diameter $(0.60 \mathrm{~cm})$ was recorded in a non-pinched plant of marigold. This revealed that pinching had a significant effect on increasing stem diameter while the non-pinched plant had a small stem diameter.

\section{Number of Flowering Plant ${ }^{-1}$}

The analysis of variance showed that pinching had a significant effect on the number of flowers in plant-1 of marigold. The mean data showed that the maximum number of flowers plant-1 (9.93) was recorded in pinched plant and the minimum number of flower plant-1 (6.44) was recorded in the nonpinched plant of marigold (Table 2). Effect of pinching on the yield of the weight of seeds per flower and seed yield per hectare in the marigold variety Sirakole was reported by Mohanty et al. (2015). The flower yield per plant was maximum in double pinching i.e., three times more yield than control (no- pinching). The present results are in conformity with the findings [4,6-12].

\section{Conclusion and Recommendation}

Pinching of marigold at 1 feet height was found more effective in producing the maximum number of branches, flower diameter, stem diameter, number of flowers and took maximum days to flower. Marigold should be pinched at 1 feet height for maximum growth and flower production.

\section{References}

1. Marigold (Tagetes) Wikipedia.

2. Kessler JR, Marigold commercial greenhouse production, Auburn University.

3. Cicevan R, MA Hassan, AF Sestras, J Prohens, Vicente O, et al. (2016) Screening for drought tolerance in cultivars of the ornamental genus Tagetes (Asteraceae). Peer J 4: e2133.

4. Arora JS, Khanna K (1986) Effect of nitrogen and pinching on growth and flower production of marigold (Tageteserecta). Indian Journal of Hort 43(3/4): 291-294.

5. Sehrawat SK, DS Dahiya, S Singh, GS Rana (2003) Studied effect of nitrogen and pinching on growth, flowering and yield of marigold 
(Tageteserecta) cv african Giant Double orange. Haryana J Hort Sci 32(1-2): 59-61.

6. Bhat Z, H Shephered (2007) Effect of pinching on growth, flowering, seed yield and quality traits in African marigold (TageteserectaLinn). J ornam Horticulture 10(3): 197-198.

7. Tomar BS, B Singh, Negi HCS, Singh KK (2004) Effect of pinching on seed yield and quality traits in African marigold. J ornam Horticulture $7(1): 124-126$.

8. Gowda JVN, Jayanthi R (1988) Studies on the effect of spacing and pinching on growth and flowering of chrysanthemum. Curr Research 17(2): 21-22.
9. Kumar R, Singh K (2003) Effect of growth regulators ad shoot tip pinching on carnation. J Ornam Horticulture 6(2): 134-136.

10. Kumar P (2011) Studied the Effect of pinching, urea and on growth, flowering and seed attributes in African marigold. Institute of Agricultural Sciences, Banaras Hindu University.

11. Anuradha RW, Sateesh RP, Kulakarni BS, Shankar Meti (2017) Studied The effect of growth regulators and pinching on economics with cost benefit ratio for commercial cultivation of marigold cv. Calcutta Orange Journal of Pharmacognosy and Phytochemistry 6(6).

12. Chauhan S, VK Dhaka (2016) Studied effects of Vermicompsot and Pinching on Marigold flower and seed. International Journal of Research in Engineering \& Applied Sciences 6(1): 2249-3905.

\section{Your next submission with Juniper Publishers} will reach you the below assets

- Quality Editorial service

- Swift Peer Review

- Reprints availability

- E-prints Service

- Manuscript Podcast for convenient understanding

- Global attainment for your research

- Manuscript accessibility in different formats ( Pdf, E-pub, Full Text, Audio)

- Unceasing customer service

Track the below URL for one-step submission https://juniperpublishers.com/online-submission.php 